\title{
SELECTING AN ALTERNATIVE STEEL MATERIAL FOR PRODUCTS WHICH STAND HIGH INTERNAL PRESSURE
}

\author{
Hashim Adam Omer Ali, M.I. Shukri \\ Department of Mechanical Engineering, Faculty of Engineering \& Technology, Nile Valley \\ University, Atbara, Sudan
}

\begin{abstract}
A practical example concerning the selection of alternative steel materials to substitute steel of chemical composition ОХНЗМФА in a part of product subjected to high internal pressure is carried to cover mainly the effect of heat treatment on the microstructures and mechanical properties of an investigated high strength low alloy (HSLA) steels1.6580 and 1.7225. The mechanical properties and microstructure of steels material were investigated.

The investigation results were compared with used steel ОХНЗМФА. The desired properties have been achieved in these steels by properly designed heat treatment. The results are quite well adopted and show that the investigated steels have excellent combination of tensile strength, impact strength and ductility which is very attractive for industrial use and also it is found that, the heattreatment and steel material costs of the investigated steels were more and more less than the old used ones.
\end{abstract}

Keywords: - Material selection, Forging, heat treatment, Mechanical properties, high strength low alloy (HSLA),

\section{INTRODUCTION}

There are numbers of products made of steel material OХНЗМФА which are possess to high internal pressure. For some reasons a different material is to be selected for these products.

This experimental research aims to select an alternative steel material.

In this case study the product is expected to stand pressure up to 87.5 bars. The strength of the steel material is the indication of this pressure. For the product uses steel materials ОХНЗМФA the strength was found to be $125 \mathrm{~kg} / \mathrm{mm}$ as max.

In this research a section process is followed to select a suitable steel material. Steels as general are selected to be a suitable alternative steel material. Steel material properties are varying according to the alloying elements and heat treatment. Two steels are found to have the required properties which are $1.6580 \& 1$. 7225.The mechanical properties are investigated for the types of steel, that include tensile test, elongation, reduction in area, impact test and hardness.
The selection problem: The selection of alternative steel material is frequently the result of several compromises. For example, the technical appraisal of alloy steel will generally be a compromise between corrosion resistance and several other properties such as strength, wear resistance, toughness and weld ability. And the final selection may come down to a compromise between technical and economic factors. For selecting steel for engineering purpose, it is important to know the required properties, the chemical composition, and microstructure of a steel casting determine its mechanical properties. [1]

The service requirements of a particular part must be matched with properties that can be supplied by the metal. The performance or functional characteristics of a material are expressed chiefly by physical, mechanical, thermal, electrical, magnetic and optical properties. Material properties are linking between the basic structure and composition of the material and service performance of the parts. [2]

The importance of different properties of a particular component depends on its final application. An important role of the materials engineer is to assist the designer in making meaningful connections between material properties and the performance of the part or system being designed. Each property will serve towards a particular application. For example, in mechanical systems tensile strength and yield strength are very important. Some of the important properties of materials are tensile strength, yield strength, shear strength, thermal conductivity, brinnel hardness, density etc. [3,4,5,]An incorrectly chosen material can lead not only to failure of the part but also add unnecessary cost.

Selecting the best material for a part involves more than selecting a material that has the properties to provide the necessary performance in service; it is also intimately connected with the processing of the material into the finished parts. $[6,7,8,9,10]$ A poorly chosen material can add to the manufacturing cost and unnecessarily increase the cost of steels has always been of interest for scientific research to understand the fundamental phenomena occurring in the microstructure.

However, the goal of industrial research is rather to use the scientific knowledge to gain technical benefits. 


\section{International Journal of Engineering Applied Sciences and Technology, 2020 Vol. 4, Issue 11, ISSN No. 2455-2143, Pages 329-333 \\ Published Online March 2020 in IJEAST (http://www.ijeast.com)}

[11,12,13] Optimizing industrial processes for efficient production, fulfilling future demands for material development and understanding critical issues (e.g. failure mechanism) to achieve a longer life time of steel products are examples of such benefits.

However, the task is not simple; the characterization of micro structural constituents and their evolution during production is a primary challenge. A critical aspect should understand as the connection between the microstructure and the mechanical properties to provide possibilities for predicting material behavior $[14,15]$

\section{EXPERIMENTAL WORK}

In this work, an attempt was made to select alternative steel for a product subjected to high internal pressure. Steels based on the chemical composition $42 \mathrm{CrMo} 4$ and $34 \mathrm{CrNi}$ Mo8 were investigated in order to produce some products subjected to high pressures settle their effectiveness in producing some products instead of utilizing steel ОХНЗМФА. The special objectives of the research work are; to carry out heat treatment process on a new alternative investigated steels 1.7225 and 1.6580 instead of used steel OXНЗМФA and evaluate the effect of heat treatment processes on the mechanical properties such as tensile strength, toughness and hardness for the new alternative investigated steels.

1) Forging process: -

The work forging of the investigated HSLA steels 1.7225 and 1.6580 is carried out in order to improve their mechanical properties through the alteration of the distribution of micro-constituents and the refinement of grain size, so as to with stand the high pressure will be subjected to the part during its working, hence all forgings have been done with both opposite surfaces of the parts were obtained parallel to ensure uniform deformation the parts were heated in an electrically heated muffle furnace at temperatures $1150-1200^{\circ} \mathrm{C}$ above the recrystallisation temperature of the steel for 30 minutes then have been forged in a 10 Tons hydraulic press with $50 \%$ or less reduction of diameter for two to three times heating were required during the process of forging to get the required reduction.

Then the forged steel parts have been cooled in normal air then annealed to facilitate the machining process to the desired shape and then hardened according to the basis of applied austenitizing temperature of $850-860^{\circ} \mathrm{C}$ for 60 minutes with cooling in a salt bath with temperature 180$200^{\circ} \mathrm{C}$ for 30 minutes followed by tempering at temperatures $400^{\circ} \mathrm{C}$ and the soaking time was 60 minutes for steel 1.7225 whereas the tempering was carried at $550^{\circ} \mathrm{C}$ and the soaking time was 60 minutes for steel 1.6580 with an aim of understanding the influence the heat treatments on microstructure and mechanical properties. The microstructures were characterized and hardness, tensile strength, elongation, reduction in area and impact toughness were evaluated.

2) Mechanical Testing of Specimens: -
Representative samples of the materials were tested in various testing machines.

\section{a) Tensile test: -}

Representative samples of heat-treated specimens of the investigated steels 1.7225 and 1.6580 were subjected to tensile testin tension to failure on the on Standard Universal Testing Machine according to ISO 6892 -1:2009 (E). The universal testing machine connected to compute and recording the tensile strength, 0.2 proof stress and elongation. The initial gauge length and diameter were measured before subjecting them to tension. Test were performed at room temperature $(20 \mathrm{C})$. The tensile load of $50 \mathrm{KN}$ was applied to the specimen up to the breaking point. The yield and maximum loads were directly from the resulted graph, the broken ends of each of the specimens were fitted and the final gauge length and also the smallest diameter of the local neck were measured. The results obtained from the tensile tests are illustrated in Tables (2\&3) below. The properties reported in these tables are the average properties of eight testing specimens.

\section{b) Impact Test: -}

The heat-treated specimens of low-alloy steels investigated. The notched impact toughness testing was produced with the dimension of $55 \times 10 \times 10 \mathrm{~mm}(1 \times \mathrm{b} \times \mathrm{h})$, respectively were subjected to impact test according to the standard ISO 148-1 :2009(E) second edition. The results obtained from the impact tests are reported in Table (2\&3) below.

\section{c) Hardness Test: -}

The hardness of an investigated heat-treated specimens of low alloy steels 1.7225 and 1.6580 were measured with the aid of Rockwell hardness tester Zwick / Roell ISO 6508 Rockwell / ASTME18 hardness tester; the Rockwell C scale. The hardness reported in this table $(2 \& 3)$ below are the average of eight testing specimens for extreme conformation.

\section{3) Microstructure Examinations: -}

Samples of heat-treated specimens of investigated low-alloy steels 1.7225 and 1.6580 were mounted in hot phenolic powder and were ground on a water lubricated hand grinding set-up of abrasive papers, progressing through from the coarsest to the finest grit sizes. The 240, 320, 400 and 600 grades were used in that order. Polishing was carried out on a rotating disc of a synthetic velvet polishing cloth impregnated with micron alumna paste. Final polishing was carried out with diamond paste. The specimens were then etched with the standard $2 \%$ nital so as to reveal the ferrite grain boundaries. The optical microscopic examinations were carried out on a metallurgical microscope at a magnification of 50X. The specimens were illuminated.

\section{RESULTS AND DISCUSSION}




\section{International Journal of Engineering Applied Sciences and Technology, 2020 \\ Vol. 4, Issue 11, ISSN No. 2455-2143, Pages 329-333 \\ Published Online March 2020 in IJEAST (http://www.ijeast.com)}

1) Tensile, Hardness and Impact Properties: -

The tensile, hardness and impact properties of the steel specimens after various heat treatment processes are shown in Tables( $2 \& 3$ ) The ultimate tensile strength ( $\sigma \mathrm{u})$ and the percentage elongation of the steel developed by the heat treatment processes for the new investigated steels 1.7225 and 1.6580 are more better than that of the used steel OXНЗМФA furthermore the impact test results acquired $22 \mathrm{~J}$. This result implied that there is a strong deformable second phase structure formed during the heat treatment process, which consist of martensite. The strong second phase is dispersed in a soft ductile ferrite matrix. The martensite provide the strength in the composite.

There is a close relationship between toughness and other mechanical properties. Within a given class of materials, there is an inverse relationship between strength and toughness. Generally, the toughness of a material is influenced by its chemical composition and microstructure.

Table (1) below shows the mechanical properties required of the used steel OXНЗМФA for comparing the results with the investigated ones.

\begin{tabular}{|l|l|}
\hline Mechanical properties required & \\
\hline Hardness HRC & $32-38$ \\
\hline Tensile strength $\mathrm{Kg} / \mathrm{mm} 2$ & $105-125$ \\
\hline Impact strength ( J ) & $\geq 17$ \\
\hline Reduction in area \% ( $\psi)$ & $\geq 25$ \\
\hline Elongation \% (ס) & $\geq 15$ \\
\hline
\end{tabular}

Table (2) mechanical test results of alternative steel material 1.7225

\begin{tabular}{|c|c|c|c|c|c|}
\hline 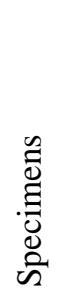 & 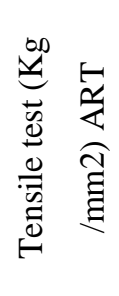 & 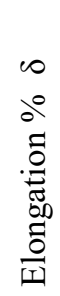 & 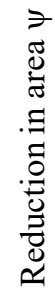 & 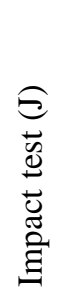 & 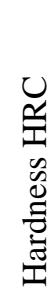 \\
\hline 1 & 121 & 15 & 30 & 18 & 36 \\
\hline 2 & 120 & 14 & 25 & 19 & 37 \\
\hline 3 & 122 & 16 & 35 & 18 & 36 \\
\hline 4 & 116 & 15 & 40 & 18 & 36 \\
\hline 5 & 117 & 18 & 30 & 20 & 36 \\
\hline 6 & 118 & 15 & 25 & 18 & 37 \\
\hline 7 & 122 & 17 & 35 & 17 & 38 \\
\hline 8 & 115 & 15 & 35 & 20 & 36 \\
\hline
\end{tabular}

Table (3) mechanical test results of alternative steel material 1.6580

\begin{tabular}{|c|c|c|c|c|c|}
\hline 冚 & 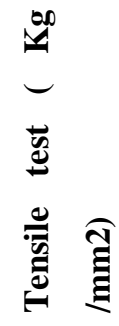 & 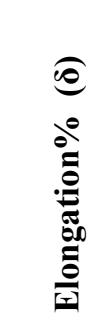 & 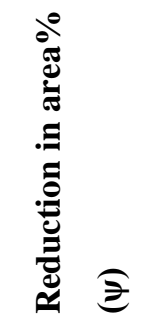 & 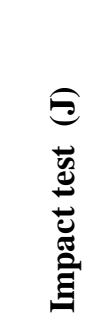 & 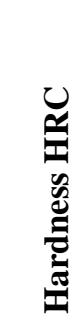 \\
\hline 1 & 117 & 14 & 30 & 20 & 34 \\
\hline 2 & 117 & 15 & 35 & 18 & 35 \\
\hline 3 & 120 & 15 & 25 & 20 & 35 \\
\hline 4 & 122 & 18 & 30 & 22 & 35 \\
\hline 5 & 118 & 19 & 35 & 17 & 36 \\
\hline 6 & 119 & 15 & 40 & 18 & 39 \\
\hline 7 & 115 & 13 & 45 & 20 & 38 \\
\hline 8 & 115 & 20 & 25 & 22 & 36 \\
\hline
\end{tabular}

Table (4) comparing the time spent during the various heattreatment processes between the old steel material $\mathrm{OXН} З \mathrm{M} Ф \mathrm{~A}$ and alternative investigated ones 1.6580 and 1.7225 .

\begin{tabular}{|c|c|c|c|}
\hline Steel & ОХНЗМ ФА & 1.6580 & 1.7225 \\
\hline $\begin{array}{l}\text { Annealing } \\
\text { for } \quad 600 \\
\text { pieces }\end{array}$ & $\begin{array}{l}2100 \min / \\
870,750,600 \\
, 680{ }^{\circ} \mathrm{C}\end{array}$ & $\begin{array}{l}240 \\
\min / \\
750^{\circ} \mathrm{C}\end{array}$ & $\begin{array}{l}120 \mathrm{~min} \\
/ 700^{\circ} \mathrm{C}\end{array}$ \\
\hline $\begin{array}{l}\text { Hardening. } \\
\text { for } \quad 160 \\
\text { piece. }\end{array}$ & $\begin{array}{l}120 \mathrm{~min} / 860 \\
{ }^{\circ} \mathrm{C}\end{array}$ & $\begin{array}{l}60 \\
\min / \\
860{ }^{\circ} \mathrm{C}\end{array}$ & $\begin{array}{l}60 \min / \\
850^{\circ} \mathrm{C}\end{array}$ \\
\hline $\begin{array}{l}\text { Tempering. } \\
\text { for } \quad 160 \\
\text { pieces }\end{array}$ & $\begin{array}{l}360 \min / 610 \\
{ }^{\circ} \mathrm{C}\end{array}$ & $\begin{array}{l}60 \mathrm{~min} / \\
550^{\circ} \mathrm{C}\end{array}$ & $\begin{array}{l}60 \mathrm{~min} / \\
450{ }^{\circ} \mathrm{C}\end{array}$ \\
\hline $\begin{array}{l}\text { Waiting for } \\
\text { cooling for } \\
600 \text { pieces }\end{array}$ & $2880 \mathrm{~min}$ & $\begin{array}{l}720 \\
\min \end{array}$ & $720 \mathrm{~min}$ \\
\hline $\begin{array}{l}\text { Total time } \\
\text { spent }\end{array}$ & $5460 \mathrm{~min}$ & $\begin{array}{l}1080 \\
\min \end{array}$ & $960 \mathrm{~min}$ \\
\hline
\end{tabular}




\section{International Journal of Engineering Applied Sciences and Technology, 2020 \\ Vol. 4, Issue 11, ISSN No. 2455-2143, Pages 329-333 \\ Published Online March 2020 in IJEAST (http://www.ijeast.com)}

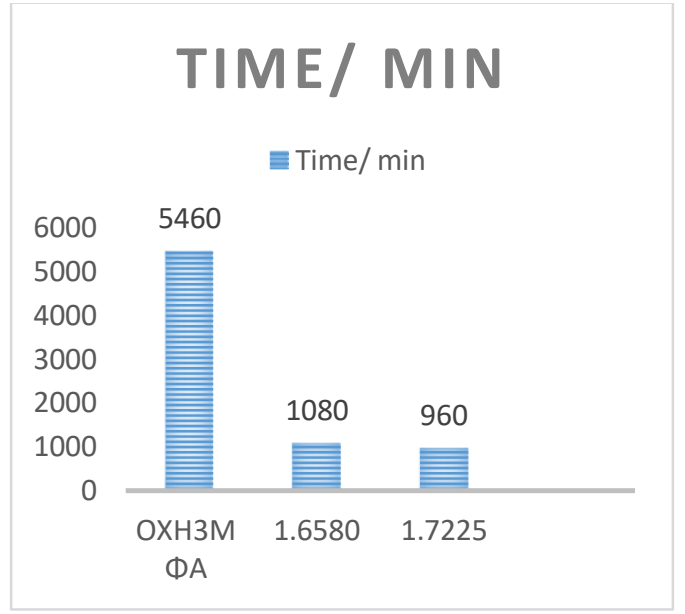

Figure (1) comparing the time spent during the various heattreatment processes between the old steel material OXНЗМФА and alternative investigated ones 1.6580 and 1.7225

Table (5) comparing the price per $\mathrm{kg}$ in USA between the used steel OXH3M $\Phi A$ and alternative investigated ones 1.6580 and 1.7225

\begin{tabular}{|c|c|c|c|}
\hline 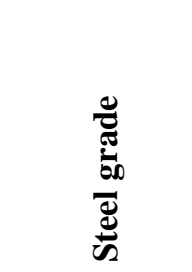 & 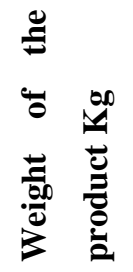 & 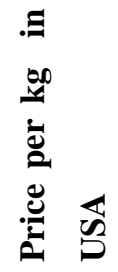 & 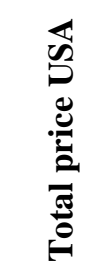 \\
\hline OXНЗМ ФА & 49 & 4.0 & 196 \\
\hline 1.6580 & 49 & 2.4 & 117.6 \\
\hline 1.7225 & 49 & 1.8 & 88.2 \\
\hline
\end{tabular}

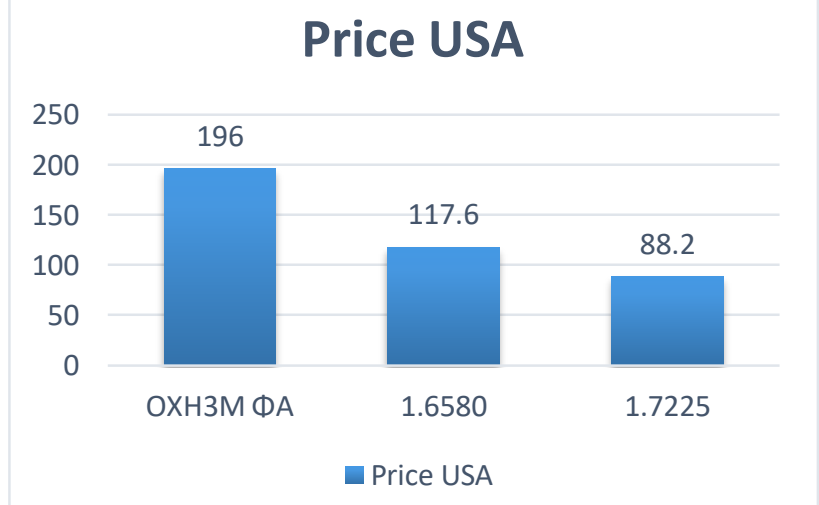

Figure (2) comparing price per kg in USA between the used steel OXH $3 \mathrm{M}$ ФA and investigated new ones

2) Micro structural characterization
The microstructure of specimens of the steel 1.6580 tempered at $500-550^{\circ} \mathrm{C}$ consists of equiaxed grain of ferrite and small rod shaped carbides that distribute within the ferrite matrix in specific direction as seen in the figure (3) related to steels. Also the dislocation cell boundaries and random dislocations situated between these cells disappear, whilst for the steel 1.7225 a fine cellular structure is developed when tempered at 400 to $450^{\circ} \mathrm{C}$ the transformation takes place from retained austenite to bainite. Bainitic structure consist of ferrite and carbide which are formed at temperature ranging between $400^{\circ} \mathrm{C}-450^{\circ} \mathrm{C}$ as shown in the figure (4) below Furthermore, low carbon martensite changes to cubic ferrite and develop toorsite structure, which consists of radial lamellae of ferrite and cementite differs from pearlite only in degree of fineness and carbon content. At these temperatures a mixture of ductility and hardness is found.

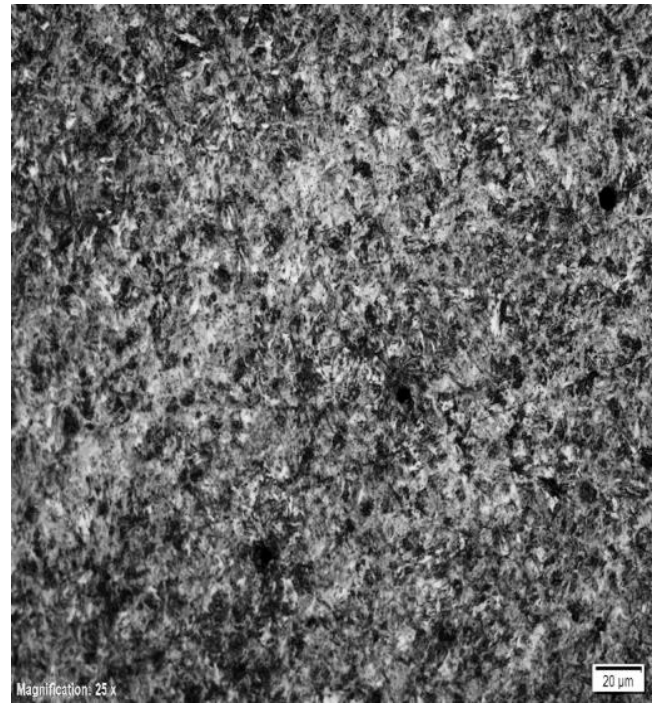

Figure (3) Optical micrograph of the tempered martensite structure of investigated steel 1.6580 .

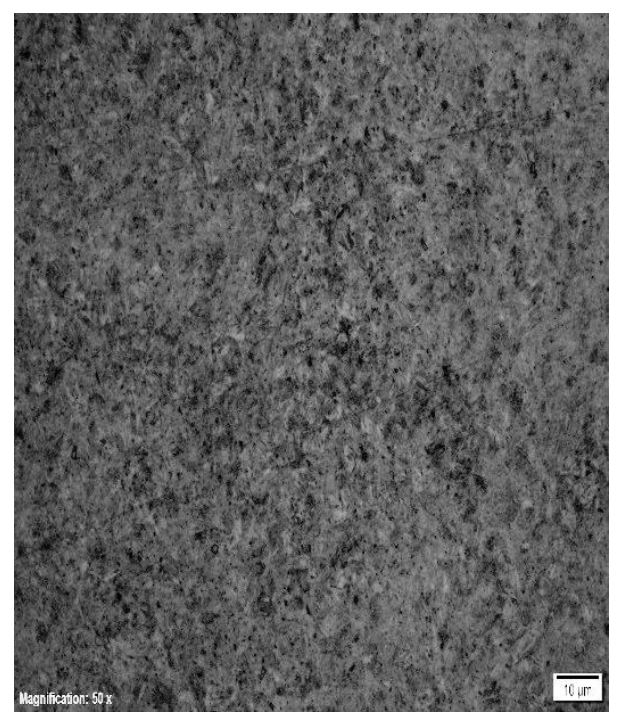

Figure (4) Optical micrograph of the tempered martensite structure of investigated steel 1.7225 . 


\section{International Journal of Engineering Applied Sciences and Technology, 2020 \\ Vol. 4, Issue 11, ISSN No. 2455-2143, Pages 329-333 \\ Published Online March 2020 in IJEAST (http://www.ijeast.com)}

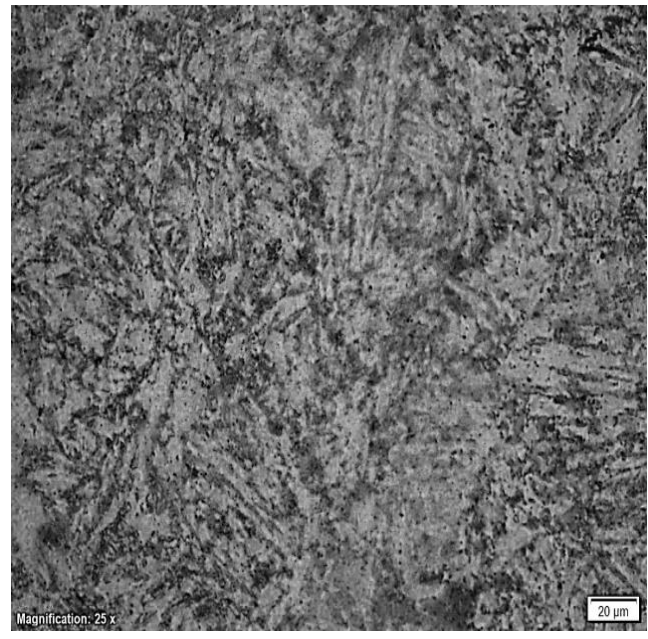

Figure (5) the microstructure is tempered Martensite of used steelOXH3M ФA consists of resolved carbide present (bainite).The quenched and tempered sample consists also of martensite and retrain austenite.

\section{CONCLUSION}

It is concluded that the selection process requires the designer to find the real data and information on the mechanical properties required, and also knowing different heat treatment techniques that improve these properties moreover.

1- The basic aspects were clarified; in particular those concerning microstructure and mechanical properties evolution as a function of heat treatment conditions.

2-The results obtained from the investigated steels showed that it has the highest ultimate tensile strength with excellent combination of impact strength, ductility and hardness which is very attractive for the company use for ensuring excellent machinability.

3-The new investigated steels has given good life time as well as the used steel OXНЗМФA.

4 -The new investigated steels acquired better mechanical properties than the used one.

5- On the other hand, according to the time cost of the heat treatment and the higher price of the used material, it is obviously the alternative steel materials is better to be used the saving money in material only is about $\$ 60000$ in using steel 1.7225 and about $\$ 100000$ in using steel 1.6580 per year in addition to the heat treatment saving which is over than the company expectations.

\section{REFERENCES}

[1]Budinski KG, and Budinski MK.( 2002 ); Engineering Materials: Properties and Selection. 7th Edition ed. New Jersey: Prentice-Hall International, Inc.(PP.350 - 355)

[2] Ermolaeva NS, Kaveline KG, Spoormaker JL (2002). Materials selection combined with optimal structural design: concept and some results. Material Design;( PP. 459-470).

[3] Budinsky K.G. and Budinsky M.K.( 1999) "Engineering Materials, Properties and Selection Prentice Hall, London, UK (PP. 430-470)
[4] Johnson KW, Langdon PM, Ashby MF.(2002) Grouping materials and processes for the designer: an application of cluster analysis. Material Design (PP.1-10).

[5] Daramola O.O, Adewuyi B.O and Oladele I.O ,(2010) Effects of Heat Treatment on the Mechanical Properties of Rolled Medium Carbon Steel, Journal of Minerals \& Materials Characterization \& Engineering, Vol.9, N0.8,( pp.693-708).

.[6]Min Shan HTUN, Si Thu KYAW and Kay Thi LWIN (2008).Effect of Heat Treatment on Microstructures and Mechanical Properties of Spring Steel, Journal of Metals, Materials and Minerals, Vol.18 No.2,( pp.191-197).

[7] X. Fang, Z. Fan, B. Ralph, P. Evans and R. Underhill,(2003). Effects of tempering temperature on tensile and hole expansion properties of a C-Mn steel, Journal of Materials Processing Technology, (pp 215-218). [8] Jamiu Kolawole odusote, Tajudeen Kolawole Ajuboye and Abdulkarim Baba Rabiu(2010). Evaluation of mechanical properties of medium carbon steel quenched in water and oil ( pp 218-224).

.[9] Ahmed Kaynar, Suleyman Gunduz and Mustafa Turkmen,(2013). Investigation on the behavior of medium carbon and vanadium micro alloyed steels by hot forging test, Materials and Design, Elsevier, (pp 819-825).

[10] S.Z. Qamar.(2009). Effect of Heat Treatment on Mechanical properties of H11 tool steel. (pp. 115 - 120).

[11] G.E. Totten (2007). Steel Heat Treatment Handbook. vol. 1. Metallurgy and Technologies, vol. 2, Equipment and Process Design, $2^{\text {nd }}$ edition. CRC Press, Boca Raton, ( pp1020-1050).

[12] ASTM International, ASTM Handbook, vol. 4,(1990). Heat Treating, American Society for Metals Park, Ohio. (Pp1020-1100).

[13] D.J. Daris and L.A. Oelmann, (1983) The structures, properties and Heat Treatment of metals. The Pitman Press, Great Britain, Vol.11, No.2 (pp896 -983).

[14] G. Yuan, W. Hu X. Wang, J. Zhai, and G . Wang, G.(2017). The relationship between microstructure, crystallographic orientation, and fracture behavior in a high strength ferrous alloy, Journal of alloys and compounds.(pp 526-535).

[15] A. Di Schino,(2016). Analysis of heat treatment effect on micro-structural features evolution in a micro-alloyed martensitic steel (pp 266-270). 